\title{
A Three-Level Analysis of Religious Texts: A Comparative Critical Discourse Analysis
}

\author{
Gebrekidan Libassie Muhie \\ College of Humanities, Language Studies and Journalism \& Communication, Department of Linguistics and \\ Philology, Addis Ababa University, P.O. Box 1176, Addis Ababa, Ethiopia
}

\section{The research is financed by...(Sponsoring information)}

\section{Abstract}

This study focuses on a three-level analysis of the two religious texts: the Bible and the Quran. The goal primarily is to do an objective and comparative analysis of the discourse used in the Bible and Quran texts. By using critical discourse analysis as a research tool, the study aims to describe, interpret and explain the discourse used in the two texts, and analyse its relation to other discourses and to social reality. Since the central concern in CDA is to trace "explanatory connections" (Fairclough 1992: 72, 80, 95) between language use (discourse) and social reality (structure), this study combines (the use of) micro- and macro-sociological analysis with linguistic analysis. In this article, one core theological theme "The Doctrine of Trinity" is selected for analysis and various Biblical and Koranic passages are drawn to corroborate a thesis about this particular theme. The findings of the study show significant linguistic as well as ideological differences between Christian and Muslim religious texts due to opposite 'truth claims' the two texts provide on the theme. The result is significant in distinguishing three types of value the formal features of the texts may have: the experiential, the relational, and the expressive.

Keywords: critical discourse analysis, linguistic practice, discursive practice (interdiscursivity, intertextuality), social practice (hegemony, ideology), experiential value, relational value, expressive value

DOI: $10.7176 /$ RHSS/11-19-01

Publication date:October $31^{\text {st }} 2021$

\section{Introduction}

\subsection{Background to the Study}

This study focuses on a three-level analysis of the two religious texts: the Bible and the Quran. It aims to describe, interpret and explain the discourse used in the two texts, and analyse its relation to other discourses within and across the two religious texts and to social reality from different theoretical perspectives. The goal primarily is to do an objective and comparative analysis of the discourse used in the Bible and Quran texts using critical discourse analysis as a research tool from a viewpoint not isolated within any one of the religions. By doing a comparative critical discourse analysis of the texts of Christian and Muslim religions, and by exploring the linguistic features, the choice of discourse used, and the modes of ideology employed in these texts, the social effects of the formal features of the texts on communal relations and patterns of religious coexistence in the two religious communities is analysed.

Though critical discourse analysis has been extensively applied to the study of communication and business studies, sociology and anthropology, in particular with regard to language use (discourse) and social reality (structure), little research to date has focused on its use on religious studies. Even though there has been relatively little focus on religious discourse within critical discourse analysis (abbreviated CDA) in the past, there has been an on-going interest in the periphery in studying how religious ideologies are shaped and reflected by discourse, and what discursive strategies characterize religious discourse from other discourse types. (See Cipriani, 2002).

\subsection{Statement of the Problem}

Religion is a source of fascination and perplexity in human history. And some people favour it, and some don't. One of the most common arguments those who don't favour religion use is that religion is the main cause of wars. If it weren't for religion, they argue, the world would be a much more peaceful place. (See Does religion cause war? by Rex Morgan, Inside Life, Issue 24, p3)

It has been observed that religion is inherently a social phenomenon, and it has many effects on the sociocultural interactions of religious communities of a certain society. The society in Ethiopia, as in other African countries, is marked by diversity and inter-religious co-existence; however, as noted by Jon Abbink (2011), it has always had some measure of religious rivalry.

Abbink (2011:253) states:

In Ethiopia, as in other parts of Africa, relations between Christians and Muslims show a new dynamic under the impact of both state policies and global connections. Religious identities are becoming more dominant as people's primary public identity, and more ideological. This development has ramifications for the 'public sphere', where identities of a religious nature are currently presented and contested in a self-consciously polemical fashion. This shared space of national, political and civic identity may become more 'fragmented' and thus lend itself to conflict 
and ideological battle.

Some of the manifestations of this emerging religious rivalry named by Abbink (2011:255) are debates about what kind of national identity the country should or should not have; more competition over public space, often in the most literal sense: when and where to build mosques, churches, or chapels; self-presentation in the media; public celebrations, and religious 'noise' production by means of loudspeakers. This polemic (polemics from Greek term 'polemikos', meaning 'warlike') competition among different religious groups is accompanied by intimidating verbal strategies which may lead to antagonistic and hegemonic religious discourses marked increasingly by declining socio-cultural interactions of the religious communities. In doing so, such rivalry not only fuel tensions but shake the very foundation of the country's unity in diversity, and also challenge the political domain - that is, the secular state order itself (Abbink, 2011:254).

What is more, the recent religiously driven conflicts observed in some parts of Ethiopia should lead to a renewed interest in evaluating the root causes of such uprising and rage over religious identities the country is experiencing in the different parts of its regions.

Here, the paradoxical implication that one must learn from another religion in order to know one's own religion could better render a meaningful solution for the tensions that could arise from the lack of understanding of other religions and their meaning to those who believe in them(See Larry Poston, 2000:9; Swatos, 2008:1). For example, both Christians and Muslims believe that they have a duty (a higher calling) to make their faith known to the world. (Matt 28:19-20; Mark 16:15) (Surah 6:19; Surah 48:8; cf. 51:55)

However, without adequate knowledge or due thought or consideration of the other's faith and its mission, or without due diligence to its people and their properties, when Christians and Muslims follow their own mission or higher calling, religiously driven conflicts are liable to occur.

Kateregga and Shenk (1980) state the problem of Muslim-Christian interaction as follows:

Hundreds of millions of Muslims and Christians are neighbors to each other. The faithful in both communities believe that they have been called by God to be witnesses. Yet they seldom hear each other's witness. The collision of their histories has created walls that separate. Although both communities worship the same God and seek to be the people of God, they seldom listen to one another. (P: xvi)

When both Muslims and Christians interact with each other within the values of their religions without understanding the other's religious values or teachings, they can be narrow-minded and consequently develop prejudice, i.e. they become xenophobic and contemptuous and judge other people's beliefs by their own religious values. Furthermore, the tendency towards religious egoism in Christian-Muslim relations has affected all levels of society, and the recent global conflicts between Muslims and Christians are evidenced by much publications and studies that have been undertaken by different scholars.

It is, therefore, imperative to quest for relevant patterns and forms of inter-religious relations in the religious and cultural experience of Ethiopia to foster peaceful co-existence. Such a paradigm could be explored with regard to the engagement of logical and effective communication within and across religious communities. As one type of discourse, religious discourse can be useful instrument for alleviating tensions and creating peaceful coexistence. This can be possible when the choice of discourse in such contexts aims to serve commonalities and unity than differences and enmity; this also entails the use of intricate mechanisms that involve psychological, social and symbolic levels of cooperation between religious groups in the construction of their religious realities.

\subsection{Objectives}

\subsubsection{General Objective}

Based on theories in discourse analysis, this study is designed with the goal of finding out the general linguistic features of the discourse used in the Bible and Quran texts. By using critical discourse analysis, the study focuses on describing, interpreting and explaining the discourse used in the two religious texts; its relation to other discourses within and across the texts and to social reality.

\subsubsection{Specific Objectives}

The specific objectives aimed at:

$>$ describing how the discourse in the religious texts is organized around the topic selected and what is achieved by such organization;

$>$ interpreting how the discourse in the religious texts relates to other discourses within and across the two texts;

$>$ explaining the relation between the discourses used in the texts and their influence on the social relations of the Christian and Muslim religious communities;

\subsection{Research Questions}

So, based on the objectives of this dissertation thesis the following research questions were designed: $1 /$ how is the discourse organized in relation to the thematic area (topic selected) and what is achieved by such organization? 2/ how does the discourse relate to other discourses within and across the religious texts? 3/ (on the subject of 
Trinity) how do the texts influence the social relations of the Christian and Muslim religious communities?

\subsection{Design}

And since discourse analysis is interpretative and explanatory, the type of research used is qualitative, and the study follows the interpretative technique of data analysis. First, the data collected from the two holy books are arranged into two categories based on individual textual dimension and then compared with one another and finally analysed.

\subsection{Significance of the Study}

Today more than ever a rational study of the communication behaviour of religions and the discourse they often employ is worth pursuing for communal harmony. Moreover, since religious discourse is pervaded by strong ideological feature, it is considered relevant to examine how ideological power is used to influence the people engaged in such communication. And since both Christians and Muslims use religious discourse to make their faith known to the world, this study is mainly undertaken with the intention that the findings could primarily increase awareness to the religious communities under study of the way their religious texts deal with the doctrine of trinity and other similar issues and this could provide them with an input that helps them to evaluate their perspectives on the way they deal with the concept of "us" and "them" and the trends of communication they follow traditionally, and if they need to change these trends for better communication and harmonious relationships with one another.

\subsection{Scope}

The study is delimited to a critical analysis of the discourse used in the two holy books of Christian and Muslim religions using Fairclough's (1992) theoretical framework of critical discourse analysis. The study has taken into consideration the evidence provided in the religious texts of the two religions. And in addition, one major recurring theme, which is considered the core theological difference (namely: The Doctrine of Trinity) is selected to limit the scope of the data.

\section{Literature review}

\subsection{Discourse}

Discourse refers to language in its social context, and is a form of 'social practice' for discourse analysis. As Kress (1989: 6) points out:

Institutions and social groupings have specific meanings and values which are articulated in the language in systematic ways. Language has always been, by its proper nature, an instrument to establish beliefs, distinguish social classes, institute prejudice, keep or transform ideologies, start revolutions, and it is used as a mechanism for numerous social struggles.

Scholars like Fairclough (1989:1-3) believe that language plays a role in the domination of some people by others, and nobody can afford to ignore this role of language in the relation of power in modern society. To be able to represent language in its social context, three different levels should constitute discourse. These are text, discursive practice, and social practice. Fairclough (1992: 72) explains:

(...) is an attempt to bring together three analytical traditions, each of which is indispensable for discourse analysis. These are the tradition of close textual and linguistic analysis within linguistics, the macro sociological tradition of analyzing social practice in relation to social structures, and the interpretive or micro sociological tradition of seeing social practice as something which people actively produce and make sense of on the basis of shared commonsense procedures.

Such structures, as Fairclough (1992: 78) claims, can give a lot of insight into the systems of knowledge and belief that are built into the conventions of text types.

The analysis in this article focuses on all the three levels and it should be noted that even though the levels are constituted of three different dimensions of discourse, they are at the same time dependent on each other and there may be situations when one level has to be mentioned in order to demonstrate something in another.

\subsubsection{Fairclough's Approach to CDA}

The central concern in critical discourse analysis (CDA), which is a specific way of conducting empirical research, is to trace "explanatory connections" (Fairclough 1992: 72, 80, 95) between language use (discourse) and social reality (structure). It combines micro- and macro-sociological analysis with linguistic analysis. And of the various methods of analysis, critical discourse analysts use are the analysis of linguistic practice, the analysis of discursive practice, and the analysis of social practice. According to Fairclough each of these dimensions requires a different kind of analysis: text analysis (description); process analysis (interpretation), and social analysis (explanation) (Fairclough, 1989: 26; 1992: 199). This three-dimensional conception of discourse is represented diagrammatically in figure 1 below (Fairclough, 1992:73). 


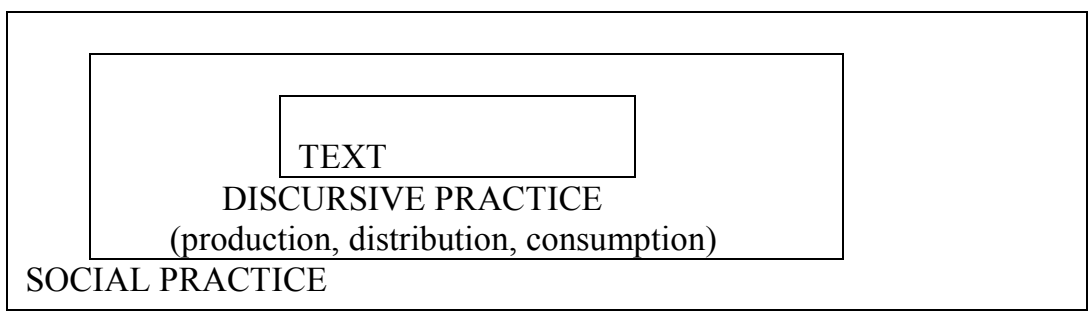

Figure 1: Three-dimensional conception of discourse

In this approach, Fairclough distinguishes between three types of value that formal features of a text may have. The first is the experiential value in which the text producer's experience of the natural and social world is represented through the content in the form of personal knowledge and beliefs. The second is the relational value in which the social relationships are enacted via the text in the discourse, and the third is the expressive value in which the producer of a text evaluates an aspect of reality or social identities. He points out that the choice of vocabulary, grammar, and textual structures to make up the formal features of a text is determined by these values.

Hence, the CDA framework adopted by Fairclough goes beyond investigating the lexical and grammatical relations of a text and acts as a possible agent of understanding the attitudinal and social interactions underlying the composition of certain discourse and as a means of social change. That is why Fairclough's approach to CDA is so useful: it provides multiple points of analytic entry.

\subsubsection{The Power of Ideology in Discourse}

By restoring the focus upon discourse in society, CDA offers an occasion to subject ideology to new methods of investigation and to formulate an explicit ideology in discourse. According to (Fairclough, 1989:33) ideological power is the power to project one's practices as universal and 'common sense' exercised in discourse. It is believed that ideology is inscribed in the discourse, and it is a way of thinking, speaking, experiencing (see Belsey, 1980: 5).

Persuasion is considered an essential tool in achieving the power of a speaker in this regard, and it also plays a prominent role in being the goal of any public or political speech. As Simons (2001: 7) defines it: persuasion is a human communication designed to influence the autonomous judgments and actions of others. There are various approaches to persuading people, and the type of persuasion is determined by the use and the type of argument in verbal behavior. Speaker's credibility (ethos) is the first important element in persuasion since the beliefs the speaker is trying to convey will not be accepted by the audience unless he is first accepted personally by them. The second element urges the listeners to believe in the proposed ideas as it appeals to their emotional and psychological motives. It is related to affect the audience emotionally, and it is termed pathos; a skillful speaker is one who is able to play on the right emotions, controlling them as he desires. The third element of persuasion is called logos, which stands for logic and reason as it appeals to the minds of the audience and has a great persuasive role (Pardo, 2001: 98).

\subsection{Theoretical framework}

This study uses critical discourse analysis as a research tool. Three analytical tools or methods of analysis suggested by Fairclough (1992:73-78, 234-237 are employed in the comparative analysis of the textual discourse. The first method used is a description, i.e. the analysis of the linguistic features of the texts (Fairclough 1992:76f., 185-194). The focus of analysis, here, is on the use of alternative wordings and their religious and ideological significance. Thus, in this stage, the wording, over wording, rewording, and alternative wording are considered. The analytical question addressed here is: How do the two texts talk about the 'Doctrine of Trinity', i.e., what words do they use? The second method is interpretation, i.e., the analysis of the meaning of the 'Doctrine of Trinity' to both the Christians and the Muslims. Here, the focus is on intertextuality and interdiscursivity. Fairclough (1992: 84) holds that people produce and consume texts by linking them to other texts. Analytic question is: How does this discourse relate to other discourses? The third method is an explanation, i.e., the analysis of the socio-cognitive effects of the texts. Here the focus is on ideology and hegemony. In this stage, the focus is on ideological language use and its effect on social relations. Analytic question is: What is the relation between language use and social reality in terms of belief systems, social identities, and social relations?

\section{Results and Discussion}

\subsection{Results}

\subsubsection{Individual Textual Dimension}

\subsubsection{The Doctrine of Trinity in the Context of the Bible}

In the context of the Bible, God is primarily described as one. However, He is also depicted as referring to Himself in the plural (this is also observed in the Qur'an). Let's see the following Biblical quotes that are used to support this: 
Table 1: Sample Biblical Quotes on the Doctrine of Trinity

1 And God said; Let us make man in our image, after our likeness: and let them have dominion over the fish of the sea, and over the fowl of the air, and over the cattle, and over all the earth, and over every creeping thing that creepeth upon the earth. (Genesis 1:26)

2 Go to, let us go down, and there confound their language, that they may not understand one another's speech. (Genesis 11:7)

3 And Jesus, when he was baptized, went up straightway out of the water: and, lo, the heavens were opened unto him, and he saw the Spirit of God descending like a dove, and lighting upon him: And lo a voice from heaven, saying: This is my beloved Son, in whom I am well pleased. (Matt 3:16-17)

4 And straightway coming up out of the water, he saw the heavens opened, and the Spirit like a dove descending upon him: And there came a voice from heaven, saying, Thou art my beloved Son, in whom I am well pleased. (Mark 1:10-11)

5 Go ye therefore, and teach all nations, baptizing them in the name of the Father, and of the Son, and of the Holy Ghost: (Matthew 28:19)

\subsubsection{The Doctrine of Trinity in the Context of the Quran}

The Doctrine of Trinity is not accepted in the Quran and there is a strong objection to the doctrine. Let's see quotes from the Quran to observe this:

Table 2: Sample Koranic Quotes on the Doctrine of Trinity

6 Lo! Allah forgiveth not that a partner should be ascribed unto Him. He forgiveth (all) save that to whom He will. Whoso ascribeth partners to Allah, he hath indeed invented a tremendous sin. (Surah 4: 48)

7 Lo! Allah pardoneth not that partners should be ascribed unto him. He pardoneth all save that to whom He will. Whoso ascribeth partners unto Allah hath wandered far astray. (Surah 4: 116)

8 O People of the Scripture! Do not exaggerate in your religion nor utter aught concerning Allah save the truth. The Messiah, Jesus son of Mary, was only a messenger of Allah, and His word which He conveyed unto Mary, and a spirit from Him. So believe in Allah and His messengers, and say not "Three"-Cease! (It is) better for you!-Allah is only One God. Far is it removed from His transcendent majesty that he should have a son. His is all that is in the heavens and all that is in the earth. And Allah is sufficient as Defender. (Surah 4: 171)

9 They surely disbelieve who say: Lo! Allah is the third of three; when there is no God save the One God. If they desist not from so saying a painful doom will fall on those of them who disbelieve. (Surah 5:73).

10 Turning unto Allah (only), not ascribing partners unto Him; for whoso ascribeth partners unto Allah, it is as if he had fallen from the sky and the birds had snatched him or the wind had blown him to a far off place. (Surah 22: 31$)$

\subsubsection{Summary of Results}

The findings of the study are summarised as follows:

\subsubsection{The Analysis of Linguistic Practice}

The phrase "let's..." used to express 'suggestion for a course of action' in English. However, in Christian theology it is used 'to suggest' the plurality (in this case 'three') of God, and since the concept of Trinity requires God the father (Godhead), God the Son, and God the Holy Spirit, that is, since it is built upon three "Biblical truths", i.e., there is One God, God exists in three distinct Persons and each of those Persons is fully God, so, here, the use of "let us..." has ideological implications for the Christian faith.

The doctrine of Trinity is evidenced by the constant use of the words: Let us..., Father, Son, and Holy Ghost. In quote 3, the Father is represented by 'a voice from heaven', and the son 'in the form of man', and the Holy Ghost in 'the form of a dove'. Many literary devices are used in the Bible, and metaphor and simile are among them.

Let us see some of the linguistic features of the above Biblical and Koranic verses (listed from 1-10):

Instances of lexical cohesion

Examples of Lexical cohesion (Reiteration and Collocation)

d) Reiteration (repetition, synonym, near-synonym, subordinate or a general class word)

The deep...the waters; language...speech; forgiveth...pardoneth; utter...say (use of a synonym)

Let us...let us (repetition); Forgiveth...forgiveth; a partner... partners; ascribed... ascribeth (use of repetition)

e) Collocation (hyponymy and antonymy, ordered sets)

Other examples:

Believe in... a messenger of...; better for...; removed from...

A voice from heaven= God the Father (Metaphor)

The spirit like a dove (Simile)

The choice of discourse and its organization in the above example verses (listed from 1-10) of the two texts is very significant in the expression of the religious ideology each religious text tries to communicate.

3.1.2.2 The Analysis of Discursive Practice

In describing the thematic area, it is mostly the Quran that links, or relates its discourse to discourses of the Bible. 
It seems that the Bible was a prior experience to the writer of the Quran. One can notice the presence within the Quran of elements of the Bible.

Obviously, as McAuliffe (2002: 315) and Coker (1931:95) assert there is both a connection and disconnection between the Bible and the Qur'an. The fact of derivation of the Qur'an from the Bible would explain how the same materials appear in both the Qur'an and the Bible.

The Quran makes a reference to Biblical books in Surah 2:136; Surah 3:3; Surah 17:55; and Surah 87: 18-19 for example. These Biblical books are the Scrolls revealed to Abraham, the Torah revealed to Moses, the Psalms revealed to David, the Gospel revealed to Jesus... (See Kateregga \& Shenk1980:25-26).

Table 3: The Intertextuality of the Bible and the Quran

\begin{tabular}{|l|l|l|l|}
\hline $\begin{array}{l}\text { Name of Book in the } \\
\text { Bible }\end{array}$ & $\begin{array}{l}\text { Related Name in } \\
\text { the Quran }\end{array}$ & $\begin{array}{l}\text { Surah(s) which indicate the names } \\
\text { in the Quran }\end{array}$ & $\begin{array}{l}\text { Revealed } \\
\text { Author(s) }\end{array}$ \\
\hline The Scrolls & Suhuf & S 87:18-19 & Abraham \\
\hline The Torah & Taurat & S 3:3, S 87:19 & Moses \\
\hline The Psalms & Zabur & S 17:55 & David \\
\hline The Gospel & Injil & S 3:3 & Jesus \\
\hline
\end{tabular}

It should be noted that just as there is a strong connection between the Bible and the Qur'an, there is also a rational indication of the disconnection between the two scriptures.

Analysis of the interdiscursivity of both books shows a particular mix of genres, of discourses, and of styles upon which the two texts draw. The Bible has many treasures of literature, and as a literature it holds many facets of literary styles: narrative history, genealogies, chronicles, laws of all kinds, poetry of all kinds, proverbs, prophetic oracles, riddles, drama, biographical sketches, parables, letters, sermons, and apocalypses.

The Qur'an contains a good deal of detail about particular incidents in the Prophet's life, but no continuous narrative - and the incidents it does relate are often told obliquely or incompletely, as if the audience knows the outline of the story already, i.e., the Qur'an often offers little context. Frequently it makes reference to people and events without bothering to explain what's going on.

\subsubsection{The Analysis of Social Practice}

There are clear differences in the belief systems of Islam and Christianity. These result from differences in their core theological "truth claims" about the nature and unity of God/Allah and the nature of Trinity to take as an example.

The Qur'an, of course, claims that the deity of Jews and Christians is the same as that of the Muslims (Surah29:46). However, since Islam rejects such Christian doctrine as the Trinity, and classifies Judaism along with Christianity as a renegade perversion of Islam, it should be reasonable to expect different language use due to such ideological differences found in the two texts.

Both Christians and Muslims identify themselves as the true believers of God/ Allah. Both claim their religion is true religion. Despite the Quran's claim that the deity of Jews and Christians is the same as that of the Muslims, the two often stand in absolute opposition about the Divine Being and His will. A believer in the Christian God could end up being the enemy of the Muslim God/ Allah and could end up in a painful doom... (Surah 5:73). According to the Quran, since Christians believe in the triune God and they profess this believe, Christians will face a painful doom.

Christian's belief in the Doctrine of Trinity centres around Jesus Christ. Furthermore, belief in Christ is the very foundation of the Christian faith. For example, if one denies Christ being the son of God and considers his death and resurrection as an utter lie, one rejects the Christian faith in its totality, and cannot understand how significantly the faith and hope of many Christians is founded on this belief. This is what the Quran literally does (Surah 4: 171; Surah 4:157-158).

In the two religious texts, discourse plays an important role in the expression of religious ideologies in terms of belief systems, identities, and relations to others. By referring to Jews, Christians, and Sabaeans "People of the scripture" the Quran expresses the domination of its ideology over these groups. In other words, it simply implies those who do not believe in Allah being only one God are unworthy of Allah's love. And the use of the phrase "Jesus/ The Messiah son of Mary" has ideological significance. It is used to show/imply that He is just a mere man, a messenger of Allah.

As can be seen, belief in one God/ Allah and the last prophet/ Muhammad is the very foundation of the Muslim society. This is the only way to salivation in Islam. There is no other way. Otherwise, one is considered a disbeliever and doomed to burning in hell fire (Surah 98:6).

And both the Bible and the Quran try to persuade individuals and groups to accept the system of beliefs, 
values etc. they are founded upon. The attempt to persuade is not without reinforcement: each give a hope of reward and warn a dire punishment! (Rev 21:27; Rev 20:15) (Surah 5:72; Surah 5:73).

\subsection{Discussion}

The purpose of the present paper was to find out the general features of the discourse used in the two holy books of Christian and Muslim religions by critically analysing the discourse of the written texts.

In the analysis of the Bible and Quran on the Doctrine of Trinity, a significant linguistic and ideological difference was observed.

The Bible depicts deity as singular, i.e., there is one and only one divine essence or Being (Deuteronomy 6:4; James 2:19). However, the Bible also alludes to a triune Being - three distinct persons within the one essencewith a triune nature. For instance, at the baptism of Jesus, while He was in human form, the Father spoke audibly from heaven, and the Holy Spirit descended on Jesus (Matthew 3:16-17).

In contrast to the Biblical portrait of God, the Quran completely denounces the notion of the Trinity (see Surah 4:171-172, cf. Surah 5:72-74). The Quran declares that those who believe in the Trinity will be excluded from paradise, and will experience a "painful doom" by burning in the hell fire.

In addition, a remarkable connection (intertextuality) is observed between the two holy books. The Quran makes many references to Biblical passages. This confirms Jane McAuliffe's (2002: 307) assertion concerning the issue of the narrative connections between the Bible and the Qur'an, that the Bible is a precursor to God's final revelation to Mohammad. It is a fact that the Qur'an shares a great deal of narrative material, such as narratives about Abraham, Moses, and Jesus, with the Bible. In this, she rightly says, "Muslim and Christian identifications meet and mingle within the Qur'an" (McAuliffe 2002:307). The co-existence of Muslim, Jewish, and Christian traditions indicated in the Qur'an would yield to the firm continuity of the Qur'an with the Bible.

Just as there is a strong connection between the Bible and the Qur'an, there is also a rational indication of the disconnection between the two Scriptures. In the argument of discontinuity between the Bible and the Qur'an, McAuliffe (2002:311) raises the Koranic charge of the corruption of the Bible and the abrogation of all previous Scriptures. The argument, it appears, is portrayed from one side, namely the Muslim point of view which assumes the Qur'an as the final and correct Scripture for the God of Jews, Christians, and Muslims. (See Surah 2: Surah 75-79; 3: 78; Surah 5:13; Surah 5:14; Surah 2:106). These verses which indicate the distortion or concealing of the Scriptures are usual scriptural supports for the Muslim accusation of the corruption of the Bible (Shenk 2006:88).

Compared to the Quran, the Bible shows a varied literary devices working together to communicate divine messages. Different genres of literature are employed mostly in the Bible.

Since both the Bible and the Quran disagree with the Doctrine of Trinity and articulate opposing views on the concept of a triune God, the mode of ideology they articulate is not one of unification.(cf Matt 12: 30; Surah 2:98).

\section{Conclusion and Recommendation \\ 4.1 Conclusions}

An important finding to emerge in this study is that due to their ideological differences concerning the Doctrine of Trinity, the linguistic features of both the Holy Books of the Christian and Muslim religions change. The result is significant in distinguishing three types of value the formal features of the texts may have: the experiential, the relational, and the expressive.

\subsubsection{Experiential Value}

Both the Bible and the Quran texts are believed to be divine revelations, and in both cases the author of these books is ostensibly believed to be God/ Allah. However, it is obvious that people who claimed they had personal experience of the spiritual world wrote them and this personal experience or encounter of the producers of these texts is represented through the form of personal knowledge and beliefs.

The choice of discourse observed across the two Holy Books is mostly determined by this experience and personal encounter of the spiritual being. For instance, Genesis, the first book of the Bible, is believed to have been written by Moses around 1440-1400 B.C. The Bible is taken from the Greek "biblos," meaning a book. As the bible is composed of many books it became known to the Greek Christians as "the books" par excellence, which title generally had fixed to it "holy," "divine," or "canonical." The name finally assumed the singular form, "through the growing conception that the Bible is one utterance of God rather than a multiplicity of voices speaking for him."

The Quran, on the other hand, is believed to have been existent in the highest (7th) heaven, but it was for some reason brought down to the third heaven, from where the angel Gabriel took it piece by piece to reveal it to the prophet Mohammad,. Mohammad then recited the Qur'an and shared it with the people around him (Nehls \& Eric 1996:53). 


\subsubsection{Relational Value}

The two holy books seem to agree on the oneness of God. They, however, differ when they deal with the Trinity of God. In Islamic ideology, because of the "Oneness of God" (Tauhid) being the fundamental basis of Islam, the association of other gods with Allah is the greatest sin (shirk) possible to a Muslim (Madany 1994:3). Based on the doctrine of the "Oneness of God," Islam, therefore, rejects the Christian concept of God as a Trinity (Pratt 1996:271; Sirry 2005:368). The concept of the Trinity is readily accepted when Jesus and Holy Spirit, understood as God, are present among the people. However, in Islam, the absolute unity of God, Tauwid, does not allow for God's presence among mankind nor the notion of the Trinity, for God is an absolute one.

\subsubsection{Expressive Value}

Both the Bible and the Quran express different realities as far as "The Doctrine of Trinity" is concerned. Each portrays a different aspect of reality or social identity.

\subsection{Recommendation}

Both the Christians and Muslims believe that their Holy Books are the written "Word of God" through God's inspiration of different writers. The Bible declares in 2 Timothy 3:16 that "all Scripture is God-breathed and is useful for teaching, rebuking, correcting and training in righteousness." The Quran in Surah 7 verse 203 also states the "Quran" is an insight from Allah. So, it is very important to see how "truthful" and "holy" these books are to the believers.

For this reason, it is recommended that believers of either holy book should make efforts to engage in the right approaches to logical and effective communication within and across Christian and Muslim religious communities residing in Ethiopia. It is believed that when both Muslims and Christians interact with each other with adequate knowledge of the other's faith and its mission and with the understanding of the other's religious values or teachings, they can and will foster peaceful co-existence and avoid religiously driven conflicts. The paradox that "one must learn from another's religion in order to know one's own religion" is true and should by no means be considered an overstatement. It could better render a meaningful solution for the tensions that could arise from the lack of understanding of other religions and their meaning to those who believe in them (See Larry Poston, 2000:9; Swatos, 2008:1).

Organized, religiously-based encounters between people from different religious traditions are found in most countries of the world, Ethiopia included. One of the most commonly expressed aims for these encounters is to increase understanding and decrease tensions across religious differences at local, national and global levels. Expecting and welcoming religious differences and seeing them crucial are a significant marker for engaging in interreligious dialogues. And these dialogues lead to a better understanding of "others".

\section{References}

Abbink, J. (2011). "Religion in Public Spaces: Emerging Muslim-Christian Polemics in Ethiopia." African Affairs, 110(439): 253-274. DOI: 10.1093/afraf/adr002

Abesha Shirko Lambebo. 2016. "Discourses on the Influence of Protestant Religious Groups on Indigenous Walaitta Culture." Asian Journal of Social Sciences, Arts and Humanities, 4(3): 2311-3782.

Belsey, C. 1980. Critical Practice. London: Hethuen.

Cipriani, A. C. (2002). Power in Religious Discourse: a Discourse Analysis of Two Sermons from the Universal Church of the Kingdom of God. (Unpublished dissertation.) Universidade Federal de Santa Catarina.

Coker, C. H. 1931. "The influence of the Bible upon the Koran: Methodist Review" 114, 94-99.

Faiclough 1989: Language and Power. London: Longman Group UK Limited.

Fairclough, N. 1992. Discourse and Social Change. London: Polity Press.

Fairclough, N. 1995. Critical discourse analysis. The critical study of language. London: Longman.

Halliday, M. And Hasan, R. 1976. Cohesion in English. London: Edward Arnorld.

Kateregga, B. D. \& Shenk, D. W. 1980. Islam and Christianity: A Muslim and a Christian in dialogue. Nairobi: Uzima.

Kress, G. 1989. Linguistic processes in sociocultural practices. Oxford: Oxford University Press.

Madany, B. M. 1994. The Bible and Islam. Palos Heights: The Back to God Hour.

McAuliffe, J. D. 2002. "Is there a connection between the Bible and the Qur'an?” Theology Digest, 49 (4): 303 315.

Nehls, G., and Eric,W. (1996). Islam: As it sees itself as others see it as it is (New revised ed.). Nairobi: Life Challenge Africa.

Pardo, M. L. 2001. "Linguistic Persuasion as an Essential Factor in Current Democracy: Critical Analysis of the Globalization Discourse in Argentina at the Turn and at The End of the Century." Discourse \& Society, 12(1): 91-118.

Poston, L. A. 2000. The changing face of Islam in America: Understanding and reaching your Muslim neighbor. Camp Hill: Horizon Books. 
Pratt, D. 1996. "Christian-Muslim theological encounter: The priority of tawhid." Islam and Christian-Muslim Relations, 7 (33):271-284.

Shenk, D. W. 2006. Journeys of the Muslim nation and the Christian church: Exploring the mission of two communities. Nairobi: Uzima.

Simons, W. H. 2001. Persuasion in Society. London: Sage Publications.

Sirry, M. A. 2005. "Early Muslim-Christian dialogue: A closer look at major themes of the theological encounter." Islam and Christian-Muslim Relations, 16 (4):361-376.

Swatos, W. H. (2008). Encyclopedia of Religion and Society. Retrieved from: http://hirr.hartsem.edu/ency/Muller.htm; Internet.

Thompson, J. B. 1990. Ideology and modern culture: Critical social theory in the era of mass communication. Stanford: Stanford University Press. 